\title{
Osmanlı Döneminde Rodos Kentindeki Camiler ve Mahalleler Üzerine Bir İnceleme
}

\section{A Research on Mosque and Neighborhood in Rhodes City in the Ottoman Period}

\section{Furkan Evliyaoğlu* (i)}

\section{Öz}

Yaklaşık 3000 yıllık kadim bir geçmişe sahip olan Rodos, 1522 yılında Saint Jean Şövalyeleri'nden alınarak Osmanlı Devleti egemenliği altına girmiştir. Bu dönemde Osmanlı Devleti adayı kuşattıktan sonra öncelikli olarak kent surlarını onarmış ve sur içi bölgesine yerleşmiştir. Ayrıca sur içi bölgesinde yer alan Bizans ve Şövalyeler dönemine ait birçok yapı yeniden işlevlendirilmiştir. Bu yapıların başında kiliseler gelmektedir. Osmanlı döneminde bu kiliseler, camiye, mescide ya da mektebe dönüştürülmüştür. Bunun yanı sıra sur içi bölgesine birçok yeni yapı inşa edilmiştir. Yine bu yapı grubunun başında camiler ve mescitler gelmektedir.

Bu çalışma kapsamında öncelikle, Osmanlı döneminde Rodos sur içi bölgesinde yer alan tüm mescitlerin ve camilerin mimari özellikleri incelenmiş, daha sonra bu yapıların plan ve kesitleri derlenerek katalog hâline getirilmiştir. Ayrıca bu yapıların hepsinin konumları mevcut Rodos haritası üzerinde gösterilmiştir. Çalışmanın ikinci aşamasında 1831 yılına ait nüfus sayımı verilerinden Rodos kentine ait mahalle isimleri elde edilmiş, bu mahalle isimleri ile dinî yapılar eşleştirilmiştir. Böylece kente ait mahalle konumlarını ve olası sınırlarını gösteren yeni bir harita üretilerek Osmanlı döneminde Rodos'un görünümü üzerine yorum yapılmıştır. Bu doğrultuda çalışma hem Osmanlı döneminde Rodos adasında bulunan tüm cami ve mescit yapılarının derlendiği katalog çalışması olarak hem de Osmanlı kentlerinde cami ve mahalle ilişkisini inceleyen bir araştırma olarak mimarlık tarihi literatürüne katkı sunmayı amaçlamaktadır.

\section{Anahtar Kelimeler}

Cami, Haritalama, Mahalle, Osmanlı mimarisi, Rodos

\begin{abstract}
Having a history of about 3000 years, Rhodes was taken from the Knights of Saint-Jean in 1522 and came under the rule of the Ottoman Empire. During this period, after the Ottoman Empire besieged the island, it primarily repaired the city walls and settled in a walled city. Later, the Ottoman Empire re-functionalized many buildings belonging to the Byzantine and Knights period. Churches are at the top of these structures. During the Ottoman period, these buildings were converted into mosques, masjids, or schools. In addition, many new buildings were built. Again, mosques and masjids are at the top of this building group.

Within the scope of this research, first, the architectural features of all the masjids and mosques in the Rhodes city wall region during the Ottoman period were examined, then the plans and sections of these structures were compiled and catalogued. In addition, the locations of all these buildings are shown on the Rhodes map. In the second section of the study, the neighborhood names of the city of Rhodes were obtained from the census data of 1831, and these
\end{abstract}

* Sorumlu Yazar: Furkan Evliyaoğlu (Arş. Gör.), İstanbul Kültür Üniversitesi, Mimarlık Fakültesi, İç Mimarlık ve Çevre Tasarımı Bölümü, İstanbul, Türkiye. E-posta: f.evliyaoglu@iku.edu.tr ORCID: 0000-0001-6433-7903

Attf: Evliyaoglu, Furkan. “Osmanlı Döneminde Rodos Kentindeki Camiler ve Mahalleler Üzerine Bir İnceleme.” Art-Sanat, 17(2022): 131-155. https://doi.org/10.26650/artsanat.2022.17.931448 
neighborhood names and religious structures were matched. Thus, a new map showing the neighborhood locations and possible boundaries of the city was produced and an interpretation was made on the appearance of Rhodes during the Ottoman period. In this direction, the study aims to contribute to the literature of architectural history, both as a catalogue study in which all mosques and masjids on the island of Rhodes during the Ottoman period are compiled and as research that examines the relationship between mosques and neighborhoods in Ottoman cities.

Keywords

Mosque, Mapping, Neighborhood, Ottoman architecture, Rhodes

\section{Extended Summary}

The archipelago in the southeast of the Aegean Sea is known as the Dodecanese Islands. This name comes from the twelve systems of the islands in the Ottoman Period. Rhodes, the largest of these archipelagoes, has a history of about 3000 years.

Having four major periods as Classical Antiquity, Byzantine Empire, Saint-Jean Knights, and Ottoman Empire, Rhodes has strategically significant potential. For this reason, Rhodes was frequently attacked by Arabs in the 7th and 9th centuries. Again, in the 14th century, Rhodes became an important target for the Genoese, Venetians, and Byzantines. On the other hand, after the Ottoman Empire conquered Istanbul, they acted many times to seize the island, however, could not win through. The last move towards the island was made in 1522 during the reign of Suleyman the magnificent. Rhodes, which joined the Ottoman lands because of this excursion, became a significant stopping point for the Ottoman navy that wanted to reach Egypt from Istanbul. Again, the island's proximity to Anatolia is an important criterion for the Ottoman Empire.

After conquering the island, Suleyman the magnificent ordered the city walls to be repaired first. Later, he issued edicts to start several construction activities in the region of the island known as the Frank Fortress. Furthermore, many churches belonging to the Knights of Saint-Jean located in the walled city region were converted into mosques. The first of these structures is known as the San Giovanni Church. After the conquest of the island, this building was transformed into a mosque and named Sencuvan Mosque. After the island was conquered, the first Friday prayer was performed in this mosque. In addition to this structure, the Santa Maria del Castello Church has also been converted into the Kanturi Mosque. Likewise, Demirli Mosque, Dolaplı Masjid, and Hurmalı Medrese Masjid are also among the structures that have been converted into a mosque or masjid.

In addition to the conversion of churches from the Byzantine and Knights period into mosques, masjids, or schools, many new structures were built in the walled city region. Foremost among these structures are mosques and masjids. Two new mosques were first built on the island with the edict of Suleyman the Magnificent. Together 
with these mosques known as Süleymaniye Mosque and İbrahim Pasha, Recep Pasha Mosque was built in later periods. Additionally, Sultan Mustafa III Mosque, Şadırvan Mosque, Agha Mosque, and Hamza Bey Mosque were built in the walled city region.

Within the scope of the study, the buildings converted into mosques or masjids and mosques and masjid structures built in the Ottoman Period are catalogued and shown on the map of Rhodes. After this process, the summary registers containing the census data of 1831 belonging to the city of Rhodes are reached. According to these data, Rhodes Island consists of twenty-three Muslim neighborhoods and two Jewish neighborhoods during the Ottoman period. The names of these neighborhoods; According to Örfi Pasha's name, these neighborhoods are named; Süleymaniye Cami District, İbrahim Paşa Mosque District, Enderun Mosque District, Demirli Cami District, Recep Paşa Cami District, Cami-i Kebir District, Tireli Hamza Bey Mescidi District, Sadri Çelebi Mescidi District, Takyeci Mescidi District, Abdülcelil Bey Mescidi District, Bored Abdi Halife Mescidi District, Piyaleddin Mescidi District, Bab-1 Mesdud Mescidi District, Alemnak Mescidi District, Kadı Mescidi District, Hüdai Mescidi District, Yeniçeli Mescidi District, Memi Şeyh Mescidi District, Çizmeci Ali Ağa Mescidi District, İlkmihrap Mescidi District, Dolaplı Mescidi District, It can be listed as Kavaklı Mescidi District and Hanzade Mescidi District.

These twenty-three neighborhoods in Rhodes, like other Muslim cities, take their names from the worship structure within their borders. Accordingly, the neighborhood names obtained are matched with the mosque and masjid structures and the locations and possible boundaries of the neighborhoods of the city of Rhodes are shown on a map.

According to this map, it can be said that the area called the Frank Fortress is the focal point or reference point of the city of Rhodes. This area, where Sultan Süleyman started the reconstruction activities after capturing the island, includes many important structure groups, particularly the Mosque-i Kebir, Süleymaniye Mosque imaret, and bathhouse, which are among the important mosques of the city.

In addition to this, it is seen that only Muslims reside in the walled city region in Rhodes, while non-Muslims live outside the castle. The two Jewish neighborhoods in the inner part of the fortress were designed concerning the port at the other end of the city, separating from the Muslim neighborhoods. Twenty-three Muslim neighborhoods in the inner part of the fortress were named after the mosque or masjid they were attached to.

Lastly, the city has developed by being positioned around the bazaar on Knight Street. In this regard, the workplaces located on both sides of Knight Street constitute an important axis. This axis is finally completed by an important structure of the city, such as the Süleymaniye Mosque. 


\section{Giriş}

Ege Denizi’nin güneydoğusunda irili ufaklı birçok adadan oluşan On İki Adalar, Menteşe Adaları ya da Güney Sporat adaları olarak bilinmektedir ${ }^{1}$. On İki Ada ismi, Osmanlı Devleti dönemindeki on ikili yönetim şeklinden gelmektedir. On İki Ada isminin Yunanca karşıllı̆ı olan dodeca-nissas (Dodecanese) diğer batı dillerine de geçmiştir. Osmanlı'da ise bu adalar yine aynı anlama gelen Cezair-i İsna Așer veya Akdeniz Adaları anlamına gelen Cezayir-i Bahr-i Sefid olarak isimlendirilmiştir².

On İki Adalar içerisinde en geniş yüz ölçümüne sahip olan Rodos, Ege'nin en büyük dördüncü adasıdır ${ }^{3}$ (G. 1). Klasik Antikite, Bizans, Şövalyeler ve Osmanlı dönemi olmak üzere dört büyük döneme tanıklık eden Rodos, 3000 yıllık kadim bir geçmişe sahiptir. Bu kapsamda Rodos, On İki Adalar içerisinde önemli bir konuma sahiptir. Fernard Braudel, Rodos'un hem Şövalyeler hem de Türkler döneminde diğer adalar üzerinde egemenlik kurduğunu ve bütün Akdeniz'in amiralliğini üstlendiğini ifade etmiştir ${ }^{4}$.

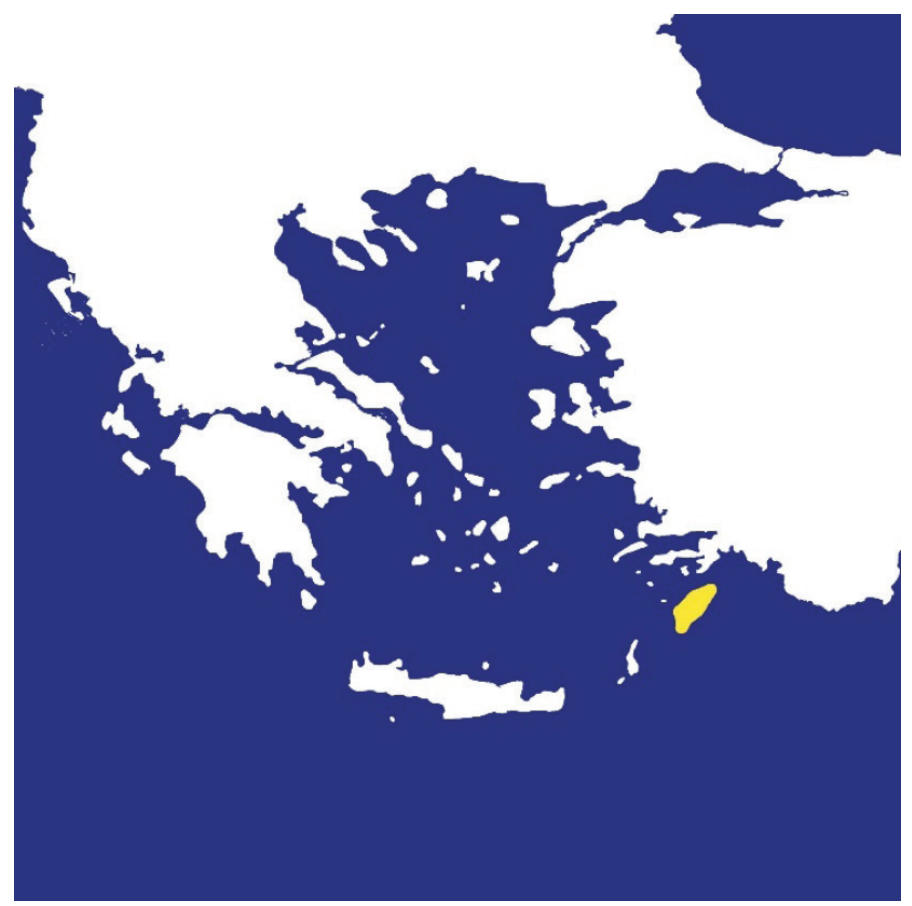

G. 1: Rodos Adası'nın konumu (Furkan Evliyaoğlu, 2021).

1 Cevdet Küçük, “Oniki Ada,” Türkiye Diyanet Vakfi İslâm Ansiklopedisi, c. 33 (İstanbul: Türkiye Diyanet Vakfi Yayınları, 2007), 353.

2 Küçük, "Oniki Ada,” 353.

3 Machiel Kiel, “Bir Taraftan İlgisizlik ve Yıkım Diğer Taraftan Özenli Onarım Arasında Rodos ve İstanköy’deki Osmanl1-Türk Mimari Eserleri,” Rodos ve İstanköy Türk Vakıflart (Konya: Eğitim Yayınevi, 2019), 205.

4 Fernard Braudel, Akdeniz ve Akdeniz Dünyası (İstanbul: Eren Yayıncılık, 1989), 93. 
$\mathrm{Bu}$ çalışma ise Osmanlı kentlerinde görülen cami-mahalle ilişkisi üzerine odaklanmış olup, Rodos kentinin mahalle kurgusu üzerine bir yorum denemesi olarak değerlendirilebilir. Bu doğrultuda Rodos kentinde cami ve mescit yapılarının mahalle kavramını nasıl etkilediği incelenmiştir. Bu kapsamda, çalışma ilk olarak 1522 yılında Osmanlı topraklarına katılan Rodos'u genel olarak ele almaktadır. Diğer bölümde Rodos mahallelerine ismini veren dinî yapılar tespit edilmiştir. Çalışmanın bu bölümü iki ayrı kısımda ele alınmıştır. Öncelikle Osmanlı döneminde daha önceki dönemlere ait yapılardan camiye ya da mescide dönüştürülen yapılar ele alınmış, son kısımda aynı dönemde inşa edilmiş olan camiler ya da mescitler incelenmiştir. Elde edilen tüm bu yapılar katalog hâline getirilerek mimari özellikleri değerlendirilmiştir. Daha sonra, tüm bu yapıların harita üzerinde konumları gösterilmiştir. Çalışmanın dördüncü bölümünde, Osmanlı kentlerindeki cami-mahalle ilişkisi odağa alınarak Rodos kenti kale içi bölgesinin mahalle kurgusu yorumlanmaya çalışılmıştır. Bu kapsamda çalışmada öncelikle kale içi bölgesinde yer alan dinî yapılara odaklanılmış daha sonra bu yapılar üzerinden olası bir mahalle kurgusu üretilmiştir.

Yapılan literatür taramasında Emma Maglio'nun “At the Periphery of the Empire: Urban Restructuring and Architectural Transformation in Ottoman Rhodes" isimli çalışması Rodos’taki mahalleleri inceleyen öncül bir çalışma olarak ele alınmıştır. Bu çalışmada, kale içi bölgesinde yer alan camiler üzerinden mahalle isimleri ve konumları önerilmiştir. Bir diğer deyişle bu çalışmada hem mahalle isimleri hem de mahallenin konumları yazarın varsayımı olarak kurgulanmıştır. Buna ek olarak bu mahalle isimleri önerilirken Rodos’ta yer alan sadece yedi büyük cami referans alınmıştır.

Bu çalışmada yapılan literatür taramasında, 1831 yılına ait nüfus sayımı verilerine ulaşılmış ve o yıla ait mahalle isimleri tespit edilmiştir. Böylece mevcut mahalle sayısının Emma Maglio’nun önerdiği üzere yedi büyük cami ile sınırlandırılmadığına ve mevcutta yirmi üç Müslüman mahallesi ile iki Yahudi mahallesi bulunduğuna dair veriler elde edilmiştir. Bu bağlamda çalışmanın dördüncü bölümünde, bir önceki bölümde haritalanan cami ve mescit yapılarına göre, Rodos mahallelerinin yerleri haritalanmıştır. Bu mahalle sınırları bir varsayım olarak kurgulanmış olsa dahi mahalle isimleri ve konumları gerçeği yansıtmaktadır. Sonuç bölümünde, oluşturulan harita referans alınarak Rodos kenti, kale içi bölgesinin cami-mahalle ilişkisi üzerinden bir değerlendirmesi yapılmıştır.

\section{Rodos'a Genel Bir Bakış}

Rodos, 1522'de Osmanlı topraklarına katıldıktan sonra Kanuni Sultan Süleyman öncelikle kuşatma sırasında top atışlarıyla hasar gören kent surlarını onartmıştır ${ }^{6}$.

5 Emma Maglio, "At the Periphery of the Empire: Urban Restructuring and Architectural Transformation in Ottoman Rhodes," Lonaard Magazine 2 (9) (2012), 1.

6 Kiel, “Bir Taraftan İlgisizlik ve Ylkım Diğer Taraftan Özenli Onarım Arasında Rodos ve İstanköy'deki Osmanll-Türk Mimari Eserleri”, 206. 
Balducci, Türklerin yaptığg sur onarımının nedenini Şövalyelerin tekrar adayı ele geçirme denemelerine bağlamıştır7. Nitekim şövalyelerin Malta adasına yerleştikten sonra Rodos'u ele geçirmek için birçok hamlesi olmuştur. Ayrıca Balducci, Türklerin yaptığı sur onarımının oldukça nitelikli olduğunu söyleyerek daha geç yıllarda yapılan onarımların bile fark edilmediğini belirtmiştir .

Kale ve burçlar onarıldıktan sonra Kanuni Sultan Süleyman, Rodos'a yerleşecek Müslüman nüfus için yeni cami ve mescitlerin yapılmasına yönelik fermanlar yayımlamıştır. Yeni imar faaliyetlerinin yanı sıra, Rodos’taki Müslüman mahallelerinin tamamına adını verecek olan bu dinî yapıların bir bölümü, adadan ayrılan Latinlere ait kilise ve şapellerin dönüştürülmesiyle elde edilmiştir ${ }^{9}$ (G. 2).

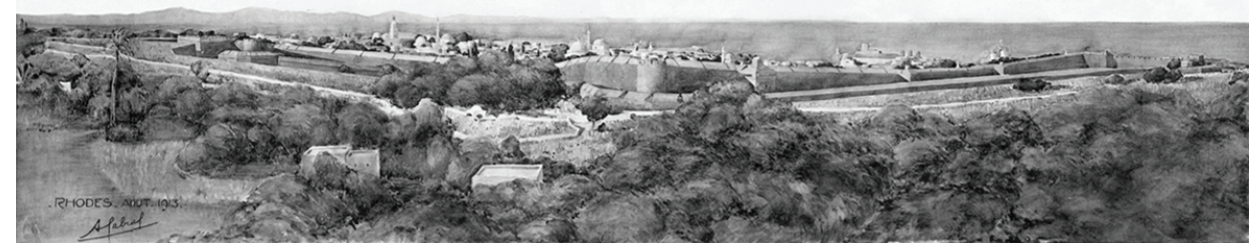

G. 2: Rodos'a genel bir bakış

(Gabriel, La Cité de Rhodes, MCCCX-MDXXII Topographie Architecture Militaire, PL.XXXIV).

Osmanlı Devleti'nde izlenen bu politikaya rağmen Rodos'a gereken önemin verilmediği sıklıkla vurgulanmaktadır ${ }^{10}$. Kiel, bu sava karşı çıksa da Rodos'un Şövalyeler döneminde küçük ama zengin bir devletin başkenti olduğunu, Osmanlı döneminde ise Cezayir-i Bahr-i Sefid Eyaleti'ne bağlı bir merkeze dönüştüğünü söylemiştir. Kiel ayrıca 17. yüzyılda İzmir'in, Akdeniz ticaretinde önemli bir liman olduğunu, Rodos limanının ikincil duruma geçtiğini belirtmiştir. Braudel, Marsilya, Livorno ve İzmir'i Akdeniz'in en canlı kentleri olarak tanımlamıştır ${ }^{11}$. Böylece Rodos, Doğu Akdeniz için önemli bir konumda yer almasına rağmen Osmanlı döneminde önemli bir liman kenti olarak görülmemiştir. Fransız yazar, Alphonse de Lamartine, Osmanlı egemenliğinde bulunan Rodos'ta iki gün dolaştığını, Şövalyeler Sokağı'nda bulunan evlerde hâlen Şövalyeler dönemine ait armaların bulunduğunu ifade etmiştir ${ }^{12}$. Raymond Matton ise üç yüz yıllık Türk dönemi içerisinde Rodos'ta yalnızca minarelerin yükseldiği-

7 Hermes Balducci, Rodos’ta Türk Mimarisi (Ankara: Türk Tarih Kurumu Yayınları, 1987), 11.

8 Balducci, Rodos 'ta Türk Mimarisi, 11.

9 Ali Fuat Örenç, Yakın Dönemimizde Rodos ve On İki Ada (İstanbul: Doğu Kütüphanesi, 2006), 181.

10 Kiel, "Bir Taraftan İlgisizlik ve Yıkım Diğer Taraftan Özenli Onarım Arasında Rodos ve İstanköy'deki Osmanl1-Türk Mimari Eserleri”, 207.

11 Fernard Braudel, Akdeniz ve Akdeniz Dünyast (İstanbul: Eren Yayıncılık, 1990), 115.

12 Alphonse de Lamartine, Oeuvres Complétes de Lamartine (Paris: Charles Cosselinet Furne Editeurs, 1836), 216-217; Zeki Çelikkol, Rodos 'taki Türk Eserleri ve Tarihçe (Ankara: Türk Tarih Kurumu Yayınları, 1986), 13. 
ni, Şövalyeler dönemine ait birçok şeyin yerinde kaldığını, yıkım olmadığı gibi yeni eserlerin de yükselmediğini belirtmiştir ${ }^{13}$. Son olarak, Hermes Balducci, 1522 ve 1912 yılları arasında adanın hemen hemen unutulmuş olduğunu savunsa da geçen bu dört yüzyıllık sürenin incelenmesinin önemli olduğunu belirtmiştirr ${ }^{14}$.

Rodos ile ilgili bütün bu savlara rağmen Osmanlı Devleti için Rodos oldukça önemli bir yere sahip olmuştur. Çünkü Rodos sayesinde Anadolu'nun Ege'deki güney sahilleri tam olarak güvence altına alınmış ve Mısır ile devletin başkenti olan İstanbul arasında güvenli bir deniz ticaret yolu oluşturulmuştur ${ }^{15}$. Bunun yanı sıra Rodos, Kıbrıs'ın alınmasında da önemli bir rol oynamıştır. Rodos, Venediklilerin Kıbrıs'a yapılacak olan yardımların önlenmesi ve bu bölgedeki gemi hareketliliğini kontrol etmesi açısından önemli bir göreve sahiptir ${ }^{16}$. Rodos, 1821 yılında gerçekleşen Yunan isyanına katılmayarak doksan bir yıl daha Osmanlı sancağı olarak kalmıştır ${ }^{17}$. Ancak 390 y1l Osmanlı egemenliği altında kalan Rodos, 17 Mayıs 1912'de diğer tüm adalarla birlikte İtalyanlar tarafından işgal edilerek kaybedilmiştir.

\section{Rodos’ta Osmanlı Dönemi Camileri}

Kanuni Sultan Süleyman, Rodos surlarını onarttıktan sonra kentin en yüksek kesimine bir dinlenme evi ve bir anıtsal cami yaptırmıştır ${ }^{18}$. Bununla birlikte Balducci, yıkılan eski Hristiyan mabetlerinin bulunduğu yerlere camilerin yapıldığını ifade etmiştir ${ }^{19}$. Balducci, yeni yapılan camilerin yanı sıra eski Yunan ve Latin kiliselerinin de büyük ölçüde onarılarak cami, mescit ve mektep olarak kullanıldığını eklemiştir. Kiel, bu dönüşümü sayısal olarak ifade ederek 1524'te surlarla çevrili Rodos kentinde on altı mescidin ve iki cuma camisinin bulunduğunu belirtmiş ve 1711'de bu sayının dört cami ve on sekiz mescide yükseldiğini ifade etmiştir ${ }^{20}$.

\section{a. Kiliseden Camiye Dönüştürülen Yapılar}

Osmanlı döneminde, mescit ya da camiye çevrilen yapılar genellikle büyük dönüşümler geçirmemişlerdir. Balducci, camiye çevrilen bu kiliselere genellikle bir minare, bir mihrap ve bir minber eklendiğini ve duvarın kalın sıvalarla örtüldüğünü ifade et-

13 Raymond Matton, Villes et Paysages de Gréce (Atina: Institu Francais D’Athenes, 1959), 64; Çelikkol, Rodos taki Türk Eserleri ve Tarihçe, 15.

14 Balducci, Rodos ta Türk Mimarisi, 9.

15 Örenç, Yakın Dönemimizde Rodos ve On İki Ada, 50.

16 Örenç, Yakın Dönemimizde Rodos ve On İki Ada, 50.

17 Kiel, “Bir Taraftan İlgisizlik ve Yıkım Diğer Taraftan Özenli Onarım Arasında Rodos ve İstanköy’deki Osmanl1-Türk Mimari Eserleri, 210.

18 Kiel, "Bir Taraftan İlgisizlik ve Yıkım Diğer Taraftan Özenli Onarım Arasında Rodos ve İstanköy'deki Osmanl1-Türk Mimari Eserleri, 206.

19 Balducci, Rodos 'ta Türk Mimarisi, 63.

20 Kiel, “Bir Taraftan İlgisizlik ve Yıkım Diğer Taraftan Özenli Onarım Arasında Rodos ve İstanköy’deki Osmanl1-Türk Mimari Eserleri, 210. 
miştir ${ }^{21}$. Bu bağlamda camiye dönüştürülen ilk yapı olarak San Giovanni Kilisesi’nden (Saint Jean) bahsedilebilir (G. 3). Şövalyeler döneminde inşa edilen katedral Rodos Kalesi'nin güneyinde yer almaktadır ${ }^{22}$. Adanın Osmanlı Devleti'ne teslim edildiği 20 Aralık 1522 'den sonra katedral camiye dönüştürülmüş ve 20 Ocak 1523 'te ilk cuma namazı k1lınmıştır ${ }^{23}$. Kilisenin çan kulesi ise artık "kelime-i tevhidin üssü olmuş ve müezzinler arzdan yükselen duaları ve huri ve meleklerle arşıâlâ sakinlerine kadar ulaştırmışlardır." 24

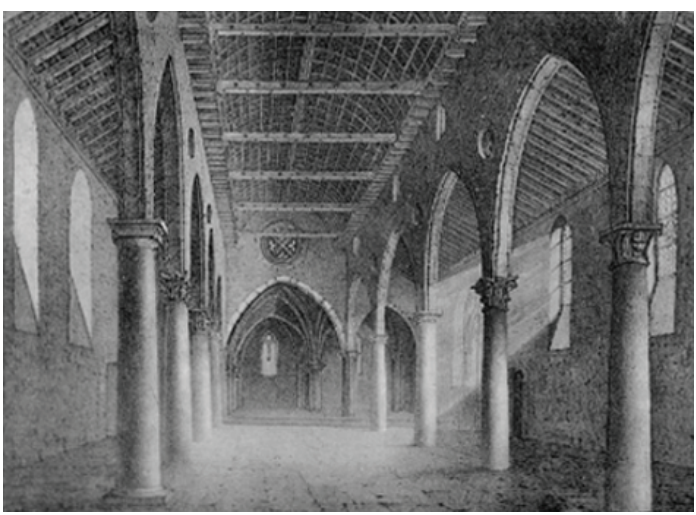

G. 3: San Giovanni Katedrali

(Gabriel, La Cité de Rhodes, MCCCX-MDXXII Architecture Civile et Religieuse, PL. XXII).

Kilise, Osmanlı döneminde Sencuvan Camii ya da Cami-i Kebir olarak anılmıştır ve bu cami, Türkler için önemli bir konumdadır ${ }^{25}$. Ancak 1856 yılının Kasım ayında meydana gelen cephanelik patlamasında yapı ağır hasar alarak yıkılmıştır ${ }^{26}$. Günümüze ulaşmayan yapının geriye kalan malzemeleri kullanılarak aynı yere Süleymaniye Medresesi inşa edilmiştir ${ }^{27}$.

San Giovanni Kilisesi'nin yanı sıra, Santa Maria del Castello Kilisesi de Osmanlı döneminde camiye dönüştürülen yapılardandır ${ }^{28}$ (G. 4). Kilise, camiye çevrildikten sonra eski ismi olan Santa Katerina'dan dolayı Kanturi Camii ismini almış daha sonra cami cemaatini oluşturan Enderunilerden dolayı Enderun Camii olarak anılmıştır ${ }^{29}$.

21 Balducci, Rodos 'ta Türk Mimarisi, 63.

22 Albert Gabriel, La Cité de Rhodes, MCCCX-MDXXII Architecture Civile et Religieuse (Paris: E. de Boccard, 1923), 67.

23 Çelikkol, Rodos 'taki Türk Eserleri ve Tarihçe, 13.

24 Ettore Rossi, Assedio e Conquista di Rodi nel 1522 Secondo le Relazioni Edite ed Inedite dei Turchi con una Notizia sulla Biblioteca Hâfiz di Rodi (Roma: Libreria Di Scienze e Lettere, 1927), 40.

25 Gabriel, La Cité de Rhodes, MCCCX-MDXXII Architecture Civile et Religieuse, 167.

26 Neval Konuk, Midilli, Rodos, Sakız ve İstanköy'de Osmanlı Mimarisi (Ankara: Stratejik Araştırma Merkezi 2008), 170.

27 Gabriel, La Cité de Rhodes, MCCCX-MDXXII Architecture Civile et Religieuse, 167.

28 Gabriel, La Cité de Rhodes, MCCCX-MDXXII Architecture Civile et Religieuse, 172.

29 Balducci, Rodos 'ta Türk Mimarisi, 68. 


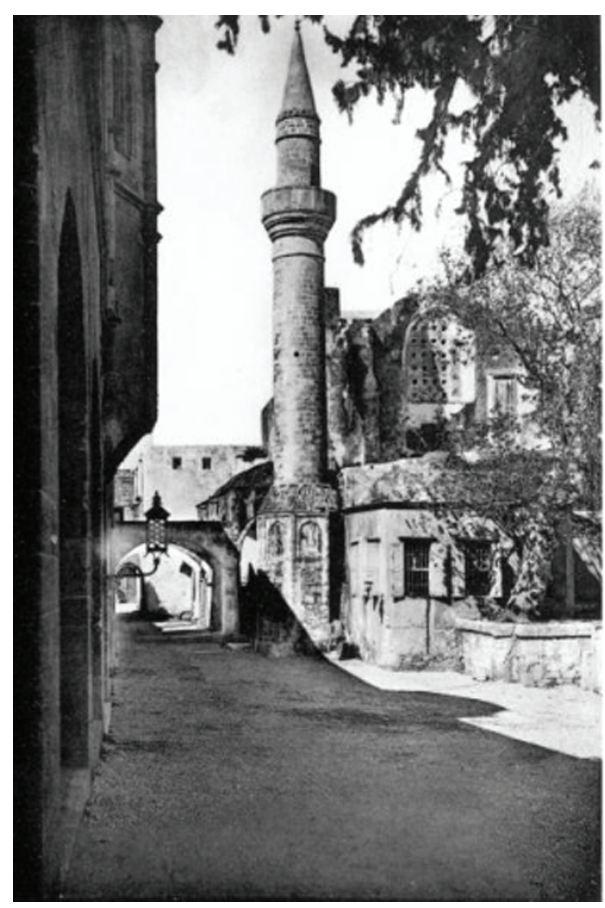

G. 4: Enderun Camii

(Gabriel, La Cité de Rhodes, MCCCX-MDXXII Architecture Civile et Religieuse, PL. XXXVI).

Yapının Şövalyeler döneminde yapılmış bir Katolik kilisesi olduğu tahmin edilmektedir. Osmanlı döneminde kilisenin cephesine üç kubbeden oluşan revak bölümü ve bu revak bölümünün yanından girilen bir minare inşa edilmiştir (G. 5). Bunun dışında camiye bir mihrap ve minber eklenmiştir. Caminin yanındaki yapıya bitişik olarak bir çeşmenin de bulunduğu bilinmektedir.

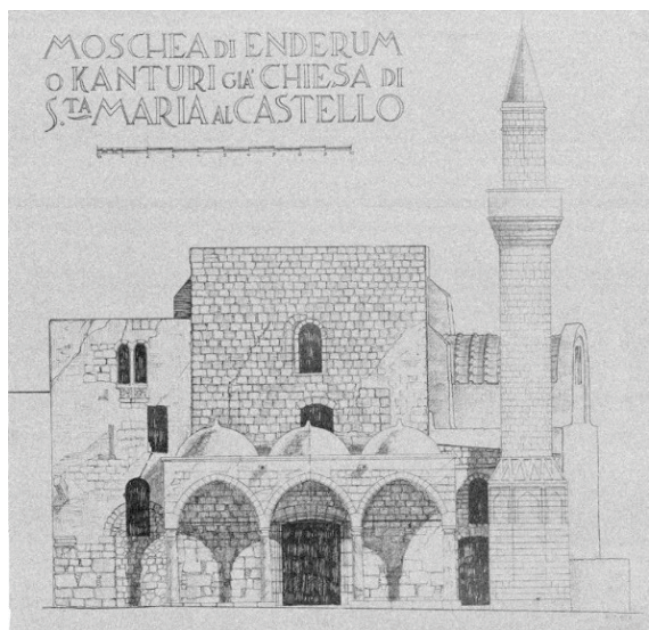

G. 5: Enderun Camii'nin ön cephesi (https://cmc.byzart.eu/items/show/88668/). 
Pencerelerinde bulunan demirlerden dolayı Demirli Camii olarak anılan bir diğer yap1, 14. yüzyıla ait bir Ortodoks kilisesinden dönüştürülmüştür. Yap1 aynı zamanda Kurt Zade Ahmet Bey Camii olarak da bilinmektedir. Haç planlı olan yapıya Osmanlı döneminde bir minare eklenmiştir (G. 6). Cami, II. Dünya Savaşı'nda ağır tahribat aldığından günümüze ulaşamamıştır.

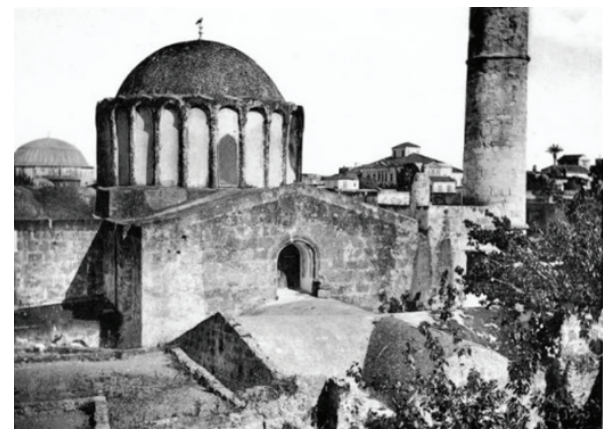

G. 6: Demirli Camii (Gabriel, La Cité de Rhodes, MCCCX-MDXXII Architecture Civile et Religieuse, PL. XXXIII).

Dolaplı Mescidi, 1400'lü y1llara ait bir Ortodoks kilisesinden dönüştürülen bir yapıdır ${ }^{30}$. Haç plan tipine sahip yapının kuzey kolu, güney kolundan daha kısa olup bir oda ile bölünmüştür. Bu oda sekizgen bir tonozla örtülü olup tonozlara açılan üç pencere ile 1şık almaktadır ${ }^{31}$. Yapıya Osmanlı döneminde bir minare eklendiği bilinmektedir (G. 7 ve G. 8). Yine bu dönemde kilisede bulunan tüm süslemeler ahşap kaplamalarla örtülmüştür. Yapının isminin de bu ahşap kaplamalardan geldiği söylenmektedir ${ }^{32}$.

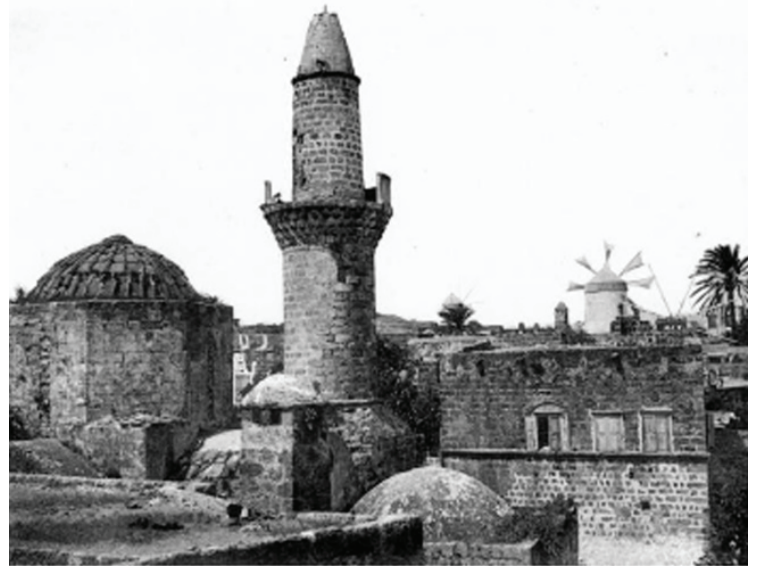

G. 7: Dolapl1 Mescit (Gabriel, La Cité de Rhodes, MCCCX-MDXXII Architecture Civile et Religieuse, PL. XXXIII).

30 Çelikkol, Rodos taki Türk Eserleri ve Tarihçe, 62.

31 Gabriel, La Cité de Rhodes, MCCCX-MDXXII Architecture Civile et Religieuse, 194.

32 Balducci, Rodos 'ta Türk Mimarisi, 67. 


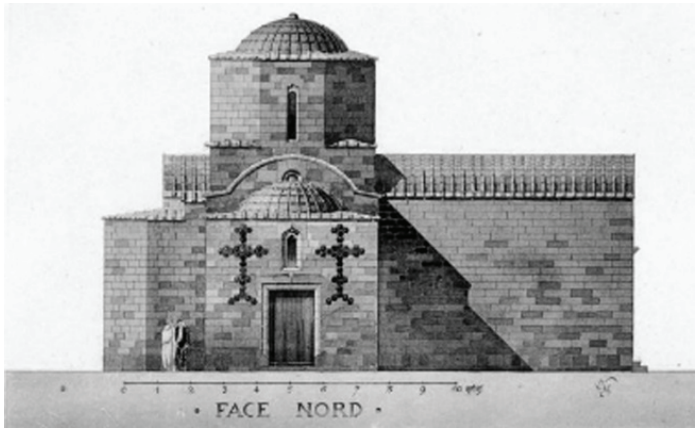

G. 8: Dolapl1 Mescidi kuzey cephesi

(Gabriel, La Cité de Rhodes, MCCCX-MDXXII Architecture Civile et Religieuse, PL. XXXV).

Son olarak incelenen Korumalı Medrese Mescidi, avlusunda bulunan hurma ağaçları nedeniyle Hurmalı Medrese Mescidi olarak da bilinmektedir ${ }^{33}$ (G. 9). Yapı bir Orta Çağ manastırı olup ortada bulunan kilise üç taraftan yapılarla çevrilmiş durumdadır. $\mathrm{Bu}$ yapılardan doğu cephesinde yer alanın daha sonradan yapıldığı düşünülmektedir. Bat1 ve kuzey cephelerde konumlanan yapılar, beşik tonozlu oda dizilerinden oluşmaktadır (G. 10 ve G. 11). Bu oda dizilerinin her biri bağımsız odalar olup kiliseyi çevreleyen avluya açılmaktadır. Osmanlı döneminde bu yapıların imaret olarak kullanıldığı söylenmektedir ${ }^{34}$. Ayrıca o dönemde iç bahçesinden geçilerek bir kız okuluna ulaşıldığı da bilinmektedir. Yapıya cadde kenarında bulunan sivri kemerli kapıdan girilmektedir. Kilisenin giriş kapısının bulunduğu iç avlu cadde kotunun altında yer almaktadır. Bu sebeple sivri kemerli kapıdan girildikten sonra beş basamaklı merdiven ile aşağı kota inilmektedir ${ }^{35}$.

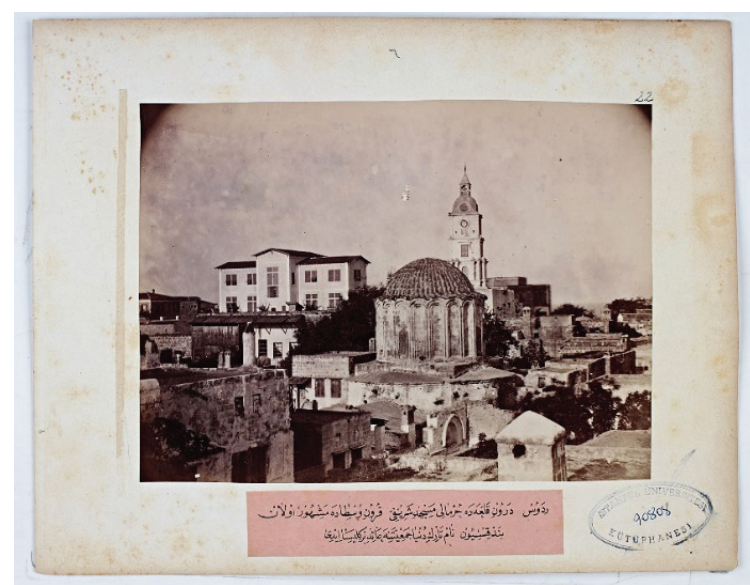

G. 9: Hurmalı Medrese Mescidi (N.E.K. Arş. No. 90808-0022).

33 Balducci, Rodos 'ta Türk Mimarisi, 67.

34 Balducci, Rodos 'ta Türk Mimarisi, 138.

35 Gabriel, La Cité de Rhodes, MCCCX-MDXXII Architecture Civile et Religieuse, 203. 


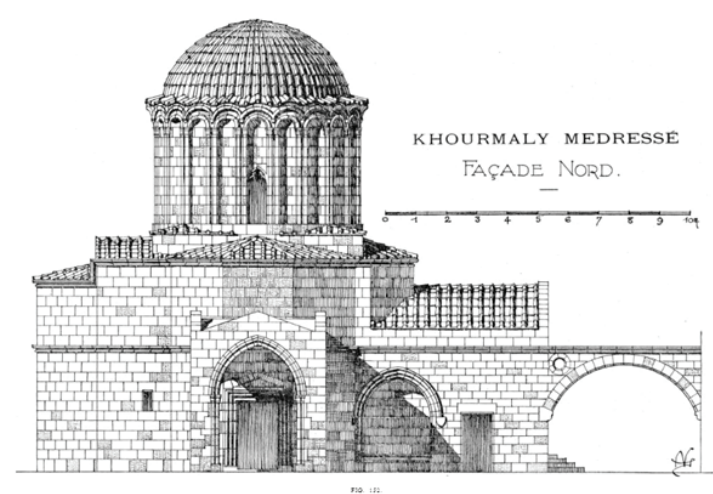

G. 10: Hurmal1 Medrese Mescidi kuzey cephesi

(Gabriel, La Cité de Rhodes, MCCCX-MDXXII Architecture Civile et Religieuse, 205).

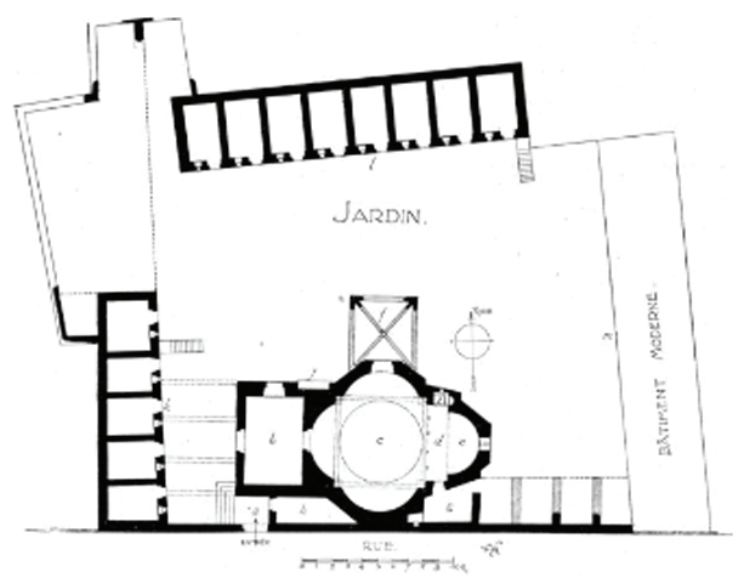

G. 11: Hurmalı Medrese Mescidi

(Gabriel, La Cité de Rhodes, MCCCX-MDXXII Architecture Civile et Religieuse, 203).

Çalışma kapsamında ele alınan bu yapıların dışında Abdülcelil Bey Mescidi, Hüdai Mescidi, Alemnak Mescidi, Bab-1 Mestur Mescidi, Piyalettin Mescidi, Sıkıntı Mescidi, Takkeci Mescidi, Sadri Çelebi Mescidi, Kavaklı Mescit, İlk Mihrap Mescidi ve Kadı Mescidi de kiliseden mescide ya da camiye dönüştürülen yapılar arasındadır (G. 12. ve G. 13). 


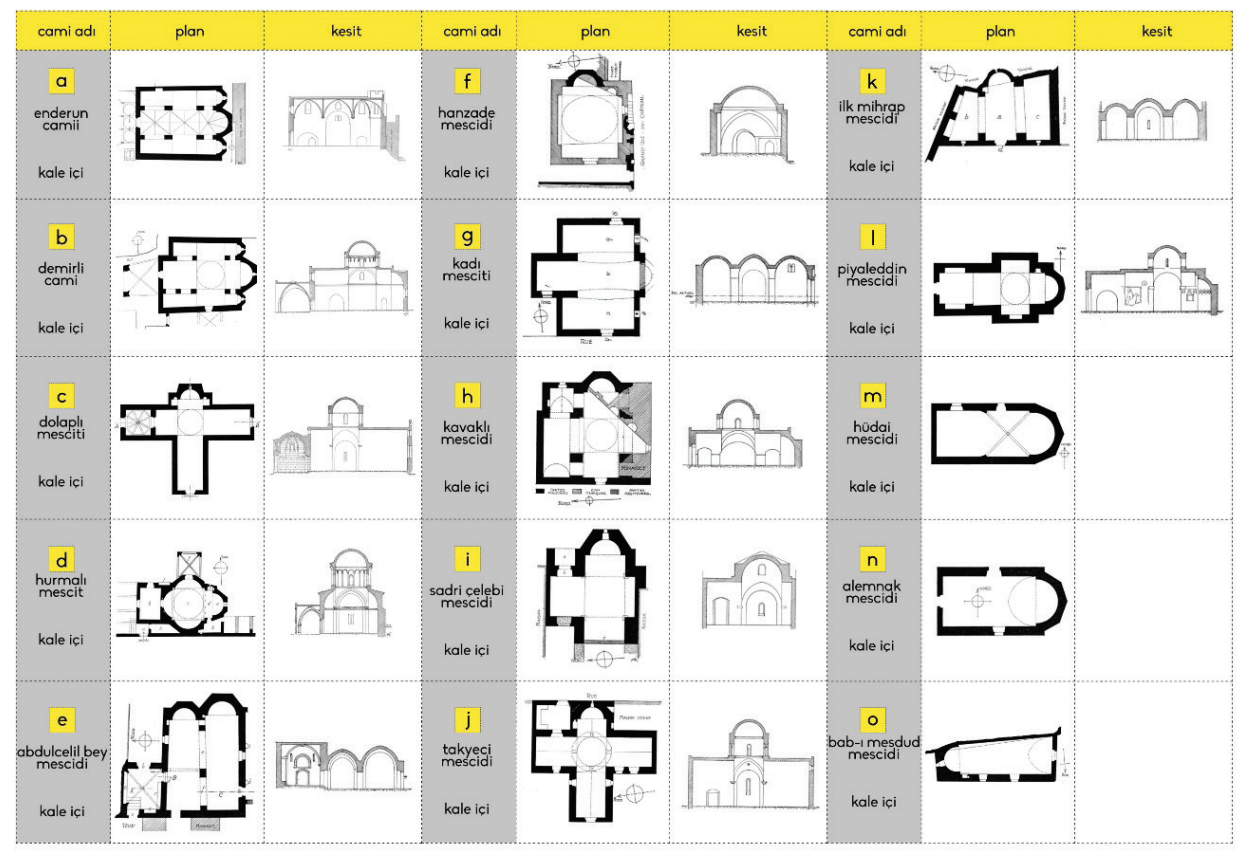

G. 12: Osmanlı döneminde, Rodos kale içi bölgesinde camiye ya da mescide dönüştürülen yapılar

(Gabriel, La Cité de Rhodes, MCCCX-MDXXII Architecture Civile et Religieuse, 167: 212'den işleyen Furkan Evliyaoğlu, 2021).

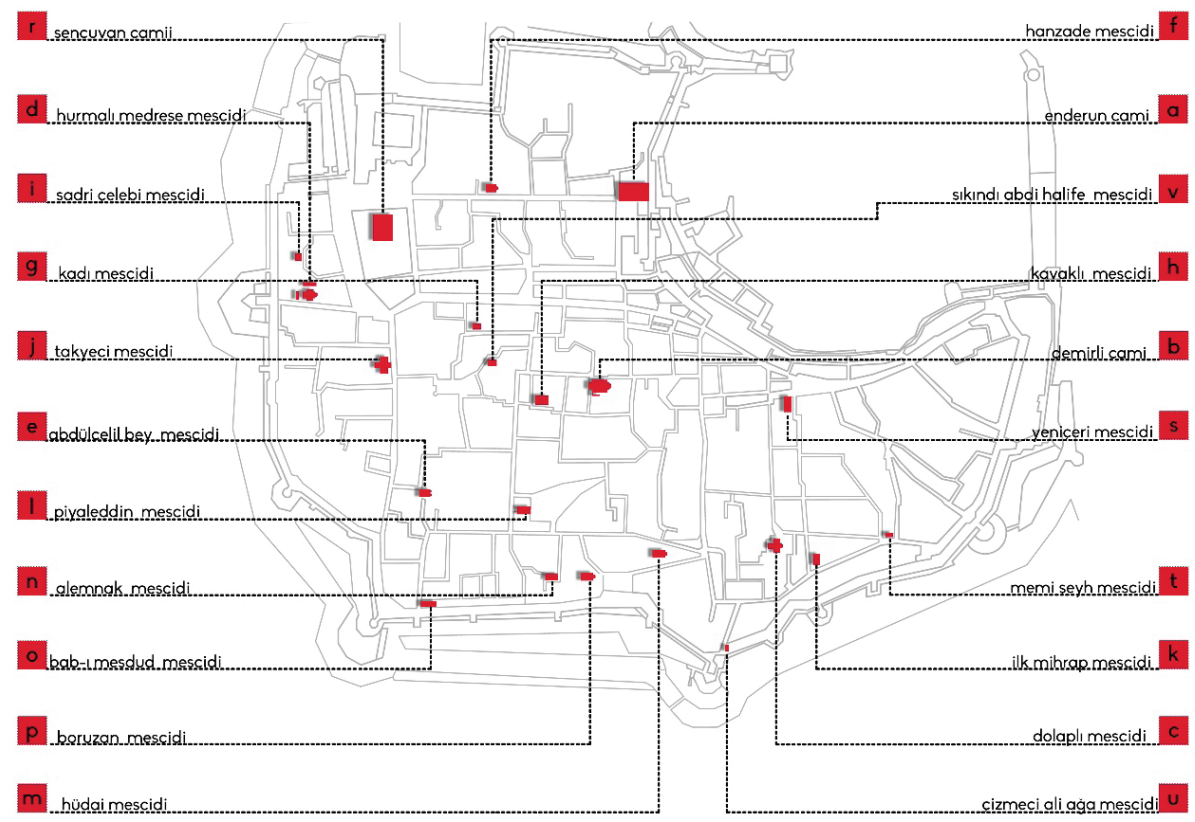

G. 13: Rodos kentinde camiye ya da mescide dönüştürülen yapıları gösteren harita (Gabriel, La Cité de Rhodes, MCCCX-MDXXII Architecture Civile et Religieuse, 3 haritasından işleyen; Furkan Evliyaoğlu, 2021). 


\section{b. Yeni İnşa Edilen Camiler}

Osmanlı egemenliğine giren Rodos’ta yapılan Türk camilerinden ilk olarak Süleymaniye Camii incelenmiştir. Süleymaniye Camii’nin adayı fethetmesinin ardından 1541 yılında, Saint Apostoli Kilise'nin bulunduğu tepeye Kanuni Sultan Süleyman tarafından bir imaret ve hamam yapısıyla birlikte inşa ettirildiği bilinmektedir. Ancak Fransız Mimar Albert-Louis Gabriel bu yapının 1808 yılında yıkılarak yeniden yapıldığını iddia etmişstir ${ }^{36}$.

Süleymaniye Camii, iki revaklı bir cami olup dış revakları kırma çatılı ahşaptır. İç revak bölümü, sekiz sütunun taşıdığ1 yedi kubbeyle örtülmüştür. Yapıya ve minareye bu revak bölümünden girilmektedir. Yapıya ait eski belgelerde minarenin silindirik ve tek şerefeli olduğu gözlemlenirken (G. 14), Balducci'nin çizimlerinde minare çift şerefeli ve prizmatik olarak gösterilmektedir. Bu durum minarenin yıkılarak tekrar yapıldığııı göstermektedir ${ }^{37}$.

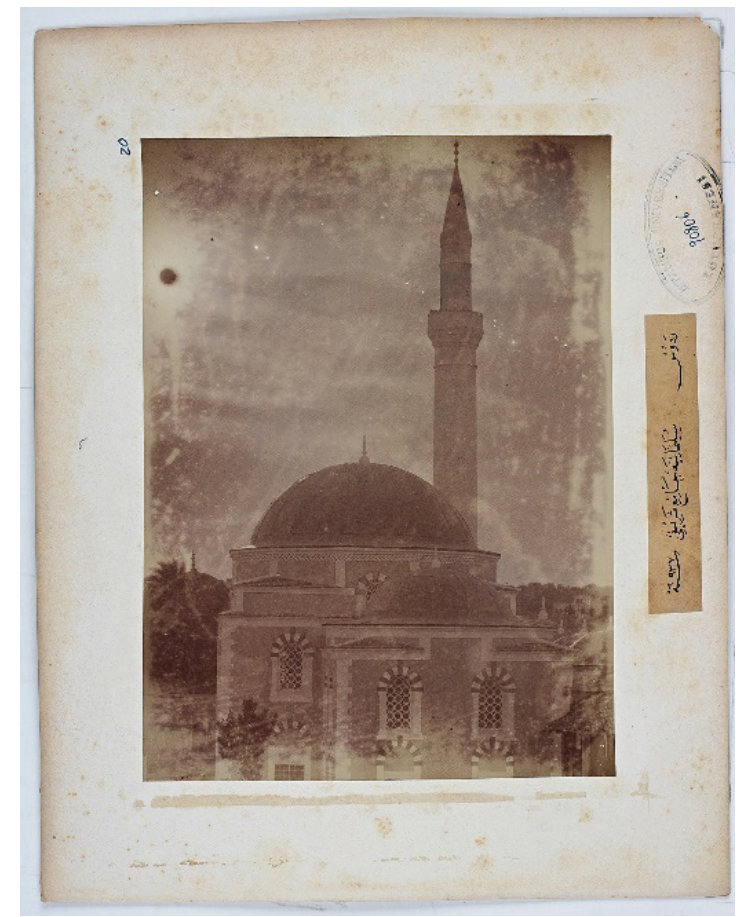

G. 14: Süleymaniye Camii (N.E.K. Arş. No. 90806-0020).

Yap1, merkezde kare bir salon ve bu ana mekâna bağlı iki yan kare salondan oluşmaktadır. Yan salonlarda da revak bölümüne açılan kapılar bulunmaktadır. Ana salon ve yan salonlar kubbe ile örtülmüş olup ana kubbe sekizgen bir kasnağa oturmak-

36 Gabriel, La Cité de Rhodes, MCCCX-MDXXII Architecture Civile et Religieuse, 203.

37 Balducci, Rodos 'ta Türk Mimarisi, 128. 
$\operatorname{tad}^{38}{ }^{38}$. Ayrıca caminin bir de şadırvanı bulunmaktadır. Sekiz sütunun desteklediği şadırvan kubbesi kemerler üzerine oturtulmuştur ${ }^{39}$.

İbrahim Paşa Camii, Osmanlı döneminde Rodos’ta inşa edilen diğer bir camidir (G. 15). Bu caminin, Kanuni'nin emri üzerine İstanbul'dan Misır'a giderken Rodos'a uğrayan İbrahim Paşa tarafından yaptırıldığg söylenmektedir ${ }^{40}$. Ancak Gabriel, Süleymaniye Camii’nin yıkılıp yeniden yapıldığını savunduğu için İbrahim Paşa Camii’ni Rodos'un en eski camisi olarak kabul etmektedir. Yap1, Süleymaniye Camii’nde olduğu gibi iki revaklıdır. İlk revak bölümü yol kotunun altında bulunduğu için merdivenlerle inilmektedir. İkinci revak bölümü ise cami duvarına yaslanmakla birlikte üç kubbelidir ${ }^{41}$. Yapının iç mekânı Süleymaniye Camii'nden farklı olarak tek salondan oluşmaktadır. On iki metre genişlikte olan ana salona, caminin revak bölümünden ulaş1lan merdivenlerle çıkılan bir mahfil uzanmaktadır. Caminin minaresi, Süleymaniye Camii'nde olduğu gibi, yıkılarak yeniden yapılmıştır. Minarenin, 1927 yılında İtalyan işgali sırasında betonarme olarak yeniden yapıldığ

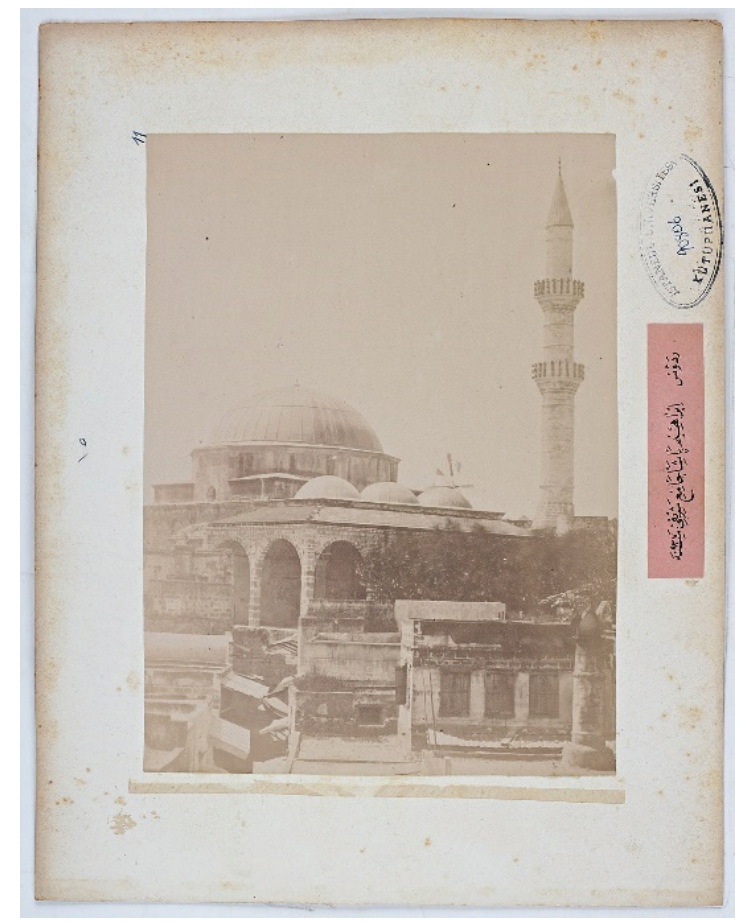

G. 15: İbrahim Paşa Camii (N.E.K. Arş. No. 90806-0011).

38 Balducci, Rodos 'ta Türk Mimarisi, 126.

39 Balducci, Rodos 'ta Türk Mimarisi, 126.

40 Çelikkol, Rodos 'taki Türk Eserleri ve Tarihçe, 53.

41 Balducci, Rodos 'ta Türk Mimarisi, 8.

42 Çelikkol, Rodos 'taki Türk Eserleri ve Tarihçe, 54. 
Recep Paşa Camii, 1588 yılında Türkler tarafından yapılmış bir diğer Rodos camisidir ${ }^{43}$. Recep Paşa Camii, İbrahim Paşa Camii gibi çift revaklıdır. Ahşap çatılı ilk revak bölümünden sonra camiye girişin olduğu ikinci revak bölümüne geçilir. $\mathrm{Bu}$ bölüm üç adet kubbeyle örtülmüştür (G. 16). Kare formda olan ana mekân, tek bir kubbeyle örtülmüştür. Diğer iki camiden farklı olarak kubbe kör olarak değil, sekiz adet pencereli olarak inşa edilmiştir ${ }^{44}$. Caminin minaresine ilk revak bölümünden ulaşılmaktadır. Minare II. Dünya Savaşı sırasında ağır tahribat almış, 1957 yılında yıktırılmıştır ${ }^{45}$.

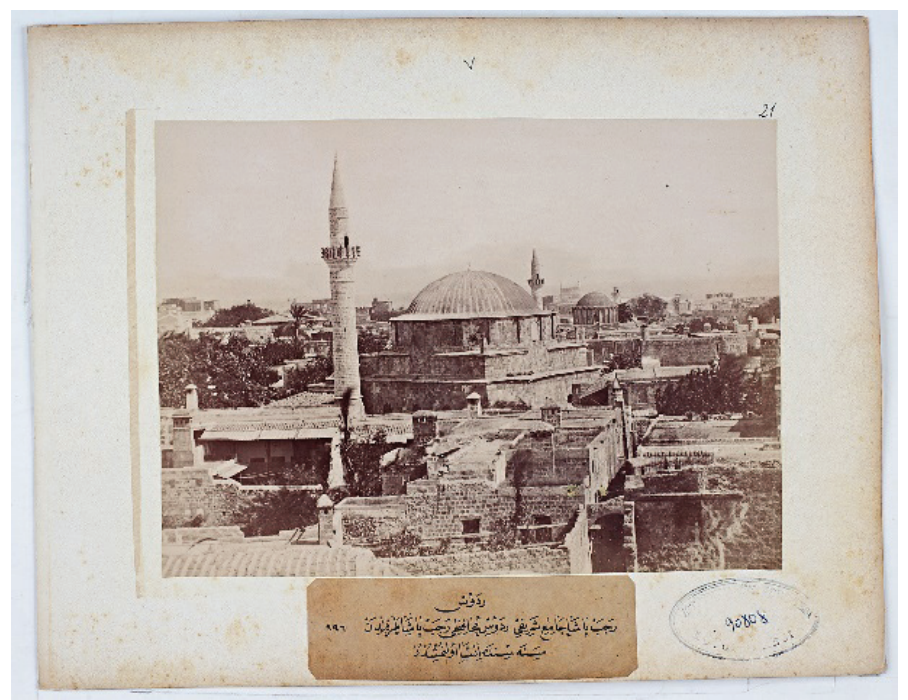

G. 16: Recep Paşa Camii (N.E.K. Arş. No. 90808-0021).

Caminin iç mekânı İznik çinileriyle kaplanmıştır. Bazı kaynaklarda çinilerin İran kökenli olduğu belirtilse de Machiel Kiel çinilerin kesinlikle en kaliteli İznik çinileri olduğunu vurgulamaktadır ${ }^{46}$. Kiel ayrıca caminin iç mekânında bulunan bu çinilerin uzun yıllar korunduğunu ancak 1976'da meydana gelen Kıbrıs olayları sırasında kasti olarak baltalarla tahrip edildiğini ifade etmiştir ${ }^{47}$.

1765 yılında inşa edilen Sultan III. Mustafa Camii’ne dört sütunun taşıdığı üç kubbeli revak bölümünden girilmektedir ${ }^{48}$. Revak bölümünde bulunan girişin yanında iki mihrap ve iki adet pencere simetrik olarak yer almaktadır. Caminin iç mekânında,

43 Balducci, Rodos 'ta Türk Mimarisi, 92.

44 Balducci, Rodos 'ta Türk Mimarisi, 104.

45 Çelikkol, Rodos 'taki Türk Eserleri ve Tarihçe, 57.

46 Kiel, “Bir Taraftan İlgisizlik ve Yıkım Diğer Taraftan Özenli Onarım Arasında Rodos ve İstanköy’deki Osmanl1-Türk Mimari Eserleri, 208.

47 Kiel, “Bir Taraftan İlgisizlik ve Yıkım Diğer Taraftan Özenli Onarım Arasında Rodos ve İstanköy’deki Osmanl1-Türk Mimari Eserleri, 208.

48 Balducci, Rodos 'ta Türk Mimarisi, 106. 
diğer camilerden farklı olarak iki adet sütun bulunmaktadır. Bu sütunlar caminin cephe duvarlarına kemerlerle bağlanmıştır ${ }^{49}$. Böylece caminin iç mekânı, ana kubbenin örttüğü bölüm, bu bölümün üç tarafında kalan dikdörtgen alanlar ve iki küçük kubbenin örttüğü iki küçük kare mekândan oluşmaktadır. Caminin ahşap bir mahfili olup bu mahfile iki küçük kare mekândan ulaşılan merdivenlerle çıkılmaktadır. Merdivenler, caminin cephe duvarı içerisine yerleştirilmiştir ${ }^{50}$. Caminin dış revak bölümünden ulaşlan minaresi ile üç kubbeli iç revak bölümü günümüze ulaşamamıştır ${ }^{51}$.

Bahsi geçen bu camiler dışında Rodos'ta kale içi bölgesinde yer alan geç dönem Osmanlı eserleri arasında sayılabilecek Şadırvan Camii, Mehmet Ağa Camii ve Hamza Bey Camii bulunmaktadır (G. 17 ve G. 18). Ayrıca kale dışında Murat Reis Külliyesi, Ali Hilmi Paşa Camii, Uzgur köyünde bulunan Muradiye Camii, Hamidiye Camii, Salakos Camii, Kataviya Camii ve Lindos Camii'nin isimleri de zikredilebilir.

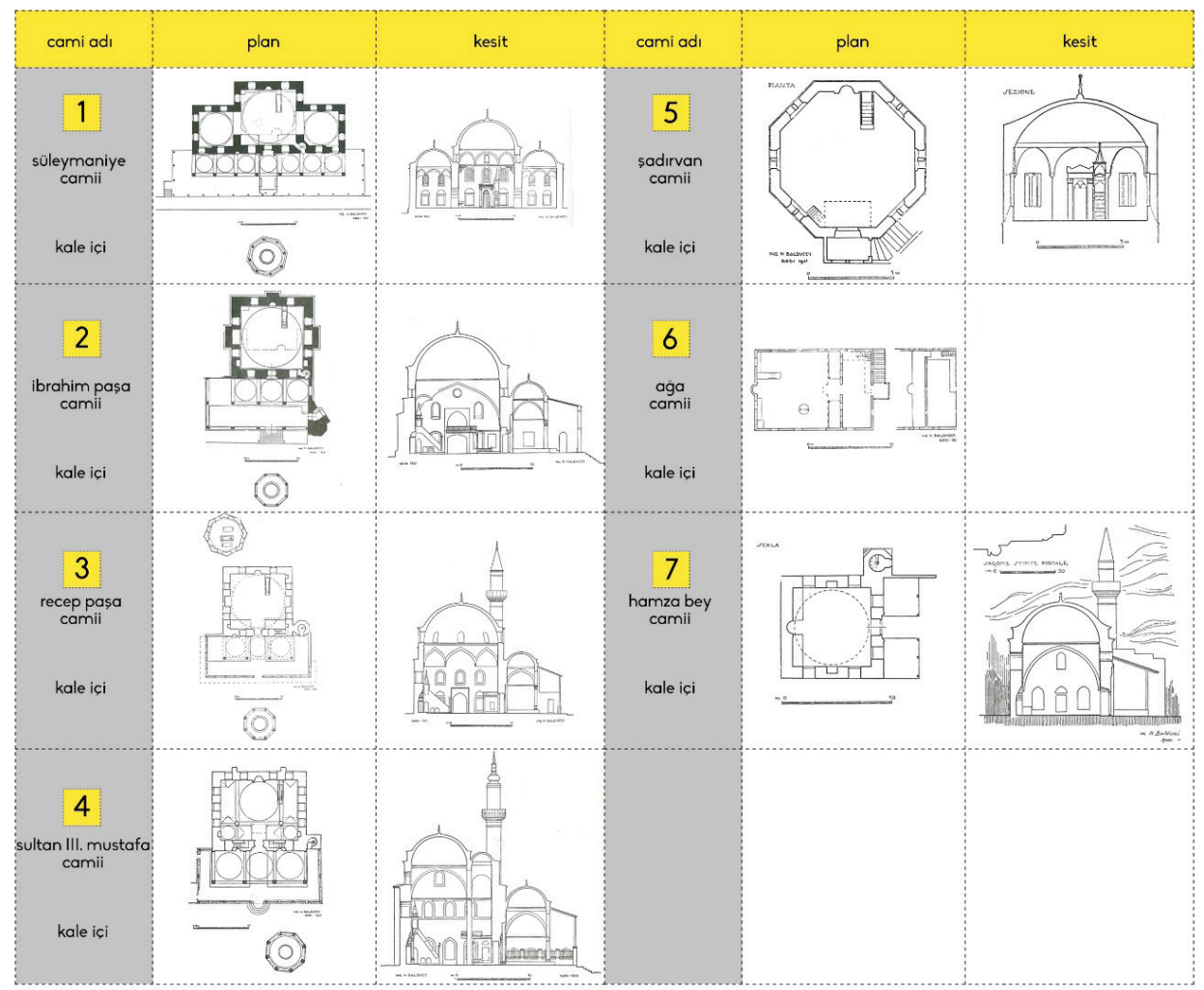

G. 17: Osmanlı döneminde, Rodos kale içi bölgesinde inşa edilen camiler (Balducci, Rodos 'ta Türk Mimarisi, 61: 124'ten işleyen Furkan Evliyaoğlu, 2021).

49 Balducci, Rodos 'ta Türk Mimarisi, 111.

50 Balducci, Rodos 'ta Türk Mimarisi, 112.

51 Çelikkol, Rodos 'taki Türk Eserleri ve Tarihçe, 53. 


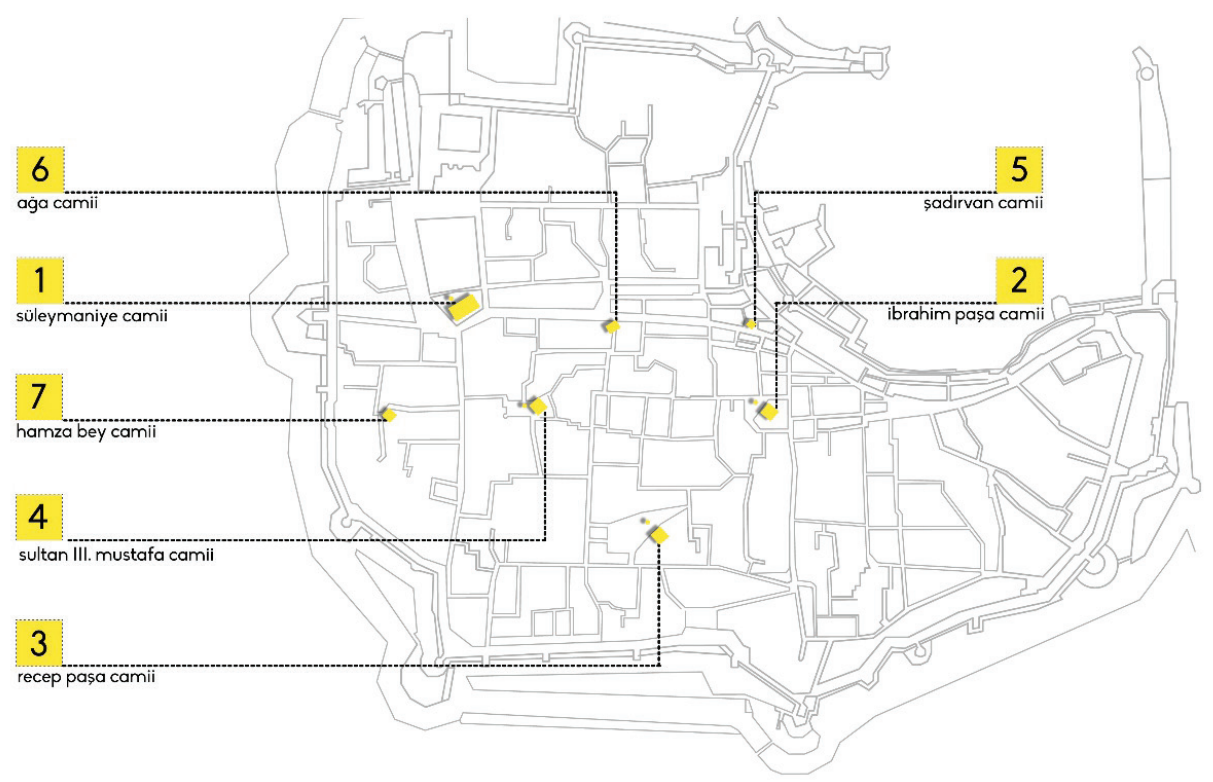

G. 18: Rodos kentinde camileri gösteren harita (Gabriel, La Cité de Rhodes, MCCCX-MDXXII Architecture Civile et Religieuse, 3 haritasından işleyen Furkan Evliyaoğlu, 2021).

\section{Rodos'ta Osmanlı Mahalleleri}

Rodos adası, eski Rodos olarak bilinen, üç katlı surlarla ve hendeklerle çevrili sur içi ve sur dışı bölgelerinden oluşmaktadır ${ }^{52}$. Sur içi bölgesinde eskiden Şövalyelerin oturduğu ve diğer bir sur ile çevrili iç kale bölgesi bulunmaktadır. Frenk Hisarı olarak bilinen bu bölge sur içi bölgesine göre eğri büğrü yollardan oluşmakta ve bir tepe üzerinde yer almaktadır. Bu bölgede, Şövalyeler döneminden kalma saraylar ile bu sarayların altında yer alan sarnıçlar bulunmaktadır. Bununla birlikte, bölgede buğday ambarlarının bulunduğu da bilinmektedir. Buna ek olarak bu civarda, kale dizdarının, kethüdanın ve bazı ağaların sarayları görülmektedir ${ }^{53}$.

Frenk hisarı bölgesinin dışındaki yerlerde, Müslüman ve Yahudi mahalleleri bulunmakta olup buralar Orta Hisar ismiyle bilinmektedir (G. 19). Halk arasında bu bölge, kale anlamına gelen Kastro ismiyle anılmaktadır.

52 Çelikkol, Rodos'taki Türk Eserleri ve Tarihçe, 17

53 Evliyâ Çelebi, Evliyâ Çelebi Seyahatnâmesi, IX. Kitap, haz. Yücel Dağlı, Seyit Ali Kahraman ve Robert Dankoff (İstanbul: Yapı Kredi Yayınları, 2005), 126-127; Bülent Çelik ve Uğur Ünen, "XVIII. Yüzyılda Rodos'un Sosyo-Ekonomik, Dinî ve Kültürel Durumu," Adnan Menderes Üniversitesi Sosyal Bilimler Enstitüsü Dergisi 2/2 (2015), 65. 


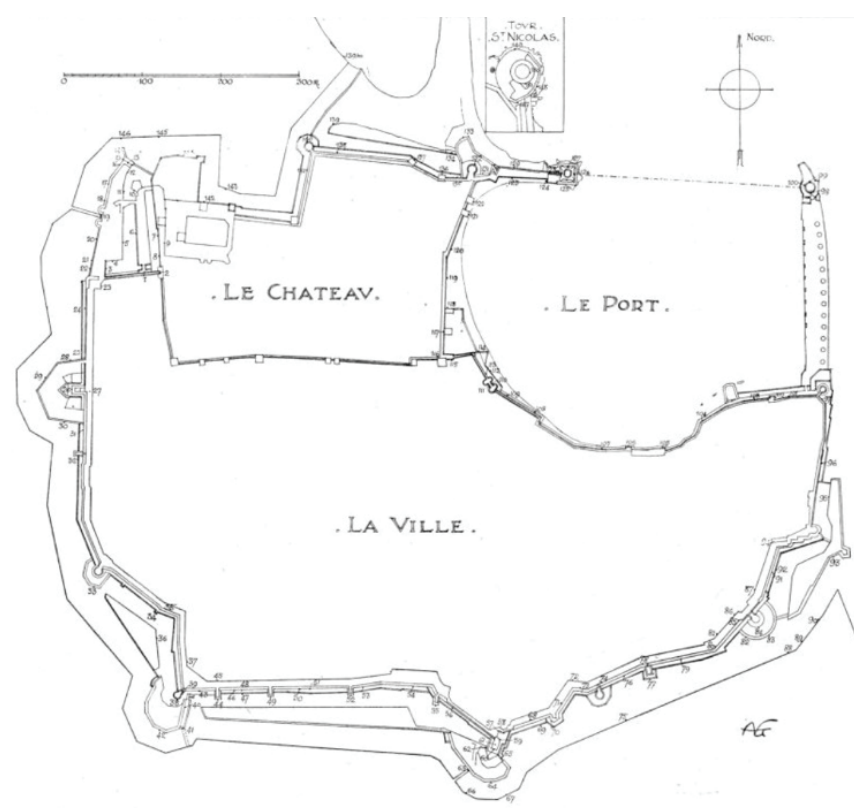

G. 19: Frenk Hisarı ve Orta Hisarı gösteren harita

(Gabriel, La Cité de Rhodes, MCCCX-MDXXII Topographie Architecture Militaire, 23).

Sur içindeki bu yerleşimlerin yanı sıra sur dışı bölgelerinde Varoşlar ve Yeni Rodos adı verilen mahalleler bulunmaktadır ${ }^{54}$. Frenk Hisarı ve Orta Hisar bölgelerinden bağımsız olarak surların dışında gelişen bu bölgelerden Varoşlar'da hemen hemen hep Türkler yaşarken, Müslümanlar, Yahudiler ve Rumların birlikte yaşadığı bölge için halk Maras tabirini kullanmıştır ${ }^{55}$. Sultan Süleyman adayı fethettikten sonra gayrimüslimlerin büyük bir bölümü güvenlik nedeniyle Varoşlar'a ya da civardaki diğer büyük köylere yerleşmiştir ${ }^{56}$. Sur içi bölgesinde yalnızca askerî garnizonların, sivil Müslüman halkın ve özel statüye sahip birkaç Hristiyan ailenin yerleşmesine izin verilmiştir.

Rodos kentindeki mahalleler ile ilgili olarak en net bilgiler, 1831 yılının nüfus sayımına ait verileri içeren icmal defterlerinden, nüfus ve cizye yoklamalarından ve vakıf kaynaklarından elde edilmektedir ${ }^{57}$. Bu kaynaklara göre Rodos Adası, yirmi üç Müslüman mahallesinden ve iki Yahudi mahallesinden oluşmaktaydı. Rodos’taki bu yirmi üç mahalle, diğer Müslüman kentlerinde olduğu gibi, isimlerini bağlı oldukları ibadet yapısından almaktadır. Çünkü İslam kentlerinde mahalle "aynı mescitte ibadet eden cemaatin aileleriyle birlikte yerleştiği şehir kesimi”" ${ }^{58}$ olarak ifade edilmektedir.

54 Örenç, Yakın Dönemimizde Rodos ve On İki Ada, 182.

55 Örenç, Yakın Dönemimizde Rodos ve On İki Ada, 182.

56 Kiel, “Bir Taraftan İlgisizlik ve Yıkım Diğer Taraftan Özenli Onarım Arasında Rodos ve İstanköy’deki Osmanl1-Türk Mimari Eserleri, 207.

57 Örenç, Yakın Dönemimizde Rodos ve On İki Ada, 182.

58 Özer Ergenç, “Osmanlı Şehirlerinde Mahallenin İşlev ve Nitelikleri Üzerine,” Osmanlı Araştırmaları IV (İstanbul: Enderun Kitapevi, 1984), 69. 
Örfi Paşa'nın adlandırmasına göre bu mahalle isimleri ve nüfusları; Süleymaniye Camii Mahallesi (84 kişi), İbrahim Paşa Camii (137 kişi), Enderun Camii Mahallesi (125 kişi), Demirli Camii Mahallesi (118 kişi), Recep Paşa Camii Mahallesi (65 kişi), Cami-i Kebir Mahallesi (141 kişi), Tireli Hamza Bey Mescidi Mahallesi (113 kişi), Sadri Çelebi Mescidi Mahallesi (63 kişi), Takyeci Mescidi Mahallesi (86 kişi), Abdülcelil Bey Mescidi Mahallesi (126 kişi), Sıkındı Abdi Halife Mescidi Mahallesi (37 kişi), Piyaleddin Mescidi Mahallesi (58 kişi), Bab-1 Mesdud Mescidi Mahallesi (73 kişi), Alemnak Mescidi Mahallesi (39 kişi), Kadı Mescidi Mahallesi (43 kişi), Hüdai Mescidi Mahallesi (116 kişi), Yeniçeli Mescidi Mahallesi (92 kişi), Memi Şeyh Mescidi Mahallesi (59 kişi), Çizmeci Ali Ağa Mescidi Mahallesi (69 kişi), İlkmihrap Mescidi Mahallesi (69 kişi), Dolaplı Mescidi Mahallesi (83 kişi), Kavaklı Mescidi Mahallesi (73 kişi) ve Hanzade Mescidi Mahallesi (102 kişi) olarak sıralanabilir.

1831 yılına ait nüfus sayımı verilerinde adı geçen mahalle isimleri ve mahallelere ismini veren cami ve mescitler eşleştirildiğinde çalışmanın üçüncü bölümünde bahsedilen Sultan III. Mustafa Camii, Şadırvan Camii ve Mehmet Ağa Camii gibi Rodos kale içi bölgesinde yer alan önemli Osmanlı camilerinin mahalle ismi olarak yer almadığı gözlemlenmektedir. Bu camiler arasında yer alan Şadırvan Camii'nin nüfus say1mının gerçekleştiği 1831 yılında henüz inşa edilmediği, yapının 19. yüzyılın sonunda inşa edildiği, bu sebeple de mahalle ismi olarak verilerde bulunmadığı söylenebilir. Yine benzer bir yorum Mehmet Ağa Camii için de yapılabilir. Mehmet Ağa Camii'nin 1831 'de henüz inşa edildiği bu sebeple de belgelerde isminin geçmediği söylenebilir. Ancak 1700'lü yıllarda inşa edilen ve Rodos için önemli bir cami konumunda yer alan Sultan III. Mustafa Camii'nin mahalle ismi olarak belgelerde geçmemesi ilginçtir. Yine çalışmanın üçüncü bölümünde camiye çevrilen yapılar arasında isimleri zikredilen Hurmalı Mescit ve Borazan Mescidi'nin de mahalle ismi olarak belgelerde yer almadığı görülmektedir. Bu durumun sebebi Hurmalı Medrese Mescidi’nin Sadri Çelebi Mescidi ile Borazan Mescidi'nin ise Alemnak Mescidi ile konum olarak çok yakın olması şeklinde yorumlanabilir.

Bu cami ve mescitler dışında çalışmanın üçüncü bölümünde isimleri zikredilen tüm cami ve mescitler mahalle ismi olarak karşımıza çıkmaktadır. Harita üzerinde yerleri gösterilen bu yapılar mahallelerin merkezinde konumlanacak şekilde ve mevcut sokak izleri referans alınarak olası mahalle sınırları oluşturulmuştur (G. 20). 


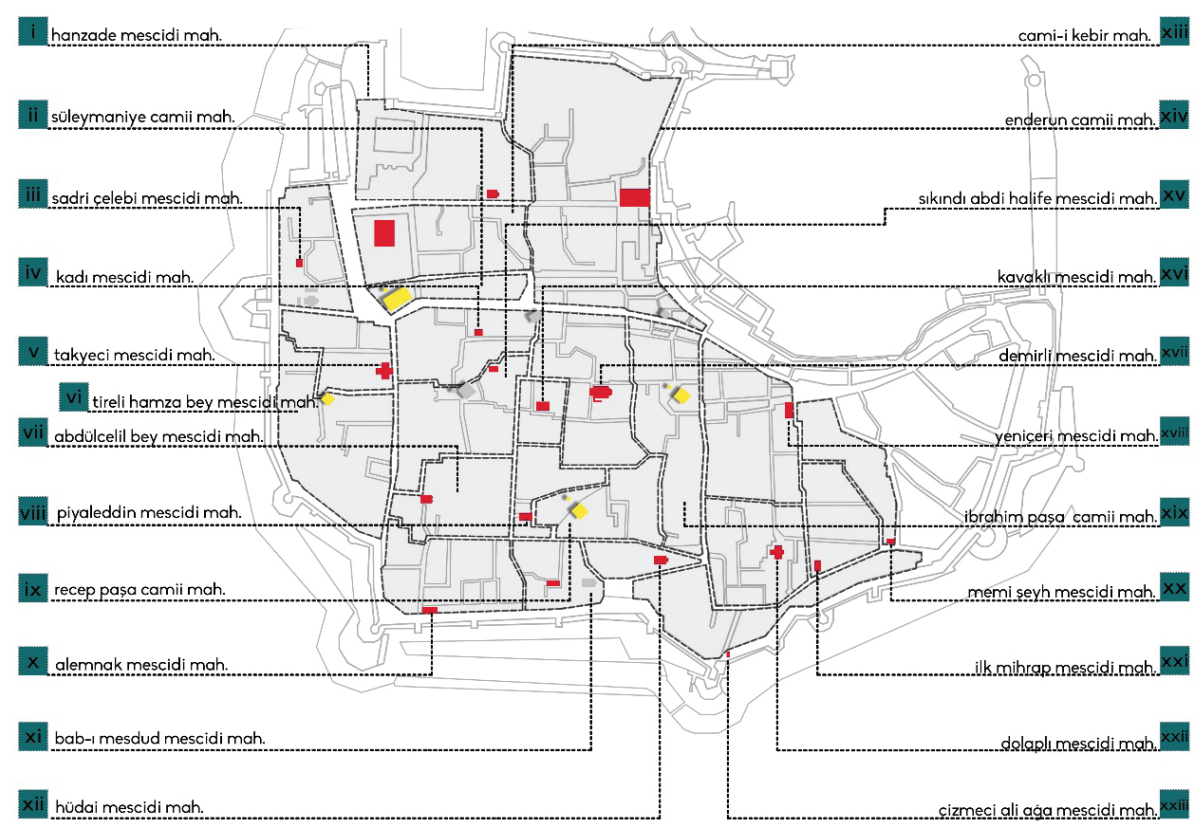

G. 20: Rodos kentinde yer alan mahalleleri gösteren harita (Gabriel, La Cité de Rhodes, MCCCXMDXXII Architecture Civile et Religieuse, 3 haritasından işleyen Furkan Evliyaoğlu, 2021).

Bu haritalamaya göre Frenk Hisarı olarak bilinen bölgede batıdan doğuya doğru Cami-i Kebir Mahallesi'nin, Süleymaniye Camii Mahallesi'nin, Hanzade Mescidi Mahallesi’nin ve Enderun Camii Mahallesi'nin yer aldığı bilinmektedir.

İlk olarak Cami-i Kebir Mahallesi ele alınabilir. Machiel Kiel, 1523’te San Giovanni Katedrali’nin Osmanlılar tarafından camiye dönüştürüldüğünü ve aynı isimle bir mahallenin de bulunduğunu söylemiştir ${ }^{59}$. Cami-i Kebir Mahallesi, 1831 yılında yapılan nüfus sayımında en kalabalık mahalle olarak ön plana çıkmaktadır. Ali Fuat Örenç de bu bilgiyi doğrular nitelikte "Türklerin adayı aldıktan sonra Müslüman mahallelerin yerleşimi özellikle Demirli Camiden Cami-i Kebir'e kadar olan aksta yoğunluk kazanmıştır”60 ifadesini kullanmıştır. Bu aksın sonunda, Süleymaniye Camii, imareti ve Hafız Ahmed Ağa Kütüphanesi'nin bulunduğu Süleymaniye Mahallesi yer $\operatorname{almaktadir}^{61}$.

Kastro olarak bilinen İç Hisar bölgesinde, en batıda Sadri Çelebi Mescidi Mahallesi, Takyeci Mescidi Mahallesi ve Tireli Hamza Bey Mescidi bulunmaktadır. Sadri Çelebi Mescidi Mahallesi, Hurmalı Mescit olarak da bilenen Korumalı Mescidi de içine almaktadır. Buna ek olarak Tireli Hamza Bey Mescidi literatürde Hamza Bey Camii

59 Machiel Kiel, "Rodos,” Türkiye Diyanet Vakfi İslâm Ansiklopedisi, c. 35 (İstanbul: Türkiye Diyanet Vakfı Yayınları, 2008), 157.

60 Örenç, Yakın Dönemimizde Rodos ve On İki Ada, 184

61 Örenç, Yakın Dönemimizde Rodos ve On İki Ada, 184 
olarak geçmektedir. Yapının hem büyüklüğü hem de 1831 yılında yapılan nüfus say1mında mahallenin nüfusunun sayıca diğer mahallelerden fazla olması, bu mahallenin sınırlarının diğer mahallelere göre daha geniş olabileceği sonucunu doğurmaktadır. Bu mahallelerin daha doğusunda, Kadı Mescidi Mahallesi, Sıkındı Abdi Halife Mescidi Mahallesi, Abdülcelil Bey Mescidi Mahallesi ve Bab-1 Mesdud Mescidi Mahallesi yer almaktadır. Kadı Mescidi Mahallesi, Rodos kentinin en önemli caddelerinden olan Sokrates Caddesi'ne komşudur. Sıkındı Abdi Halife Mescidi Mahallesi mahalle listesinde adı yer almayan Sultan III. Mustafa Camii ve yanında yer alan Yeni Hamam'1 kapsamaktadır. Bu mahallenin hemen güneyinde Abdülcelil Bey Mescidi Mahallesi bulunmaktadır. Bu mahalle surlarla sınırı bulunan ve kentin en güney batısında yer alan Bab-1 Mesdud Mescidi Mahallesi ile komşudur.

Bu hattın yanında, Demirli Camii Mahallesi yer almaktadır. Bu mahallenin Mehmet Ağa Camii'ni de içerisine alarak Sokrates Caddesi'ne kadar uzandığı düşünülmektedir. Yine 1831 yılı nüfus sayımına göre diğer mahallelerden daha fazla nüfusa sahip olan bu mahallenin daha geniş sınırlara sahip olabileceği düşünülmüştür. Bununla beraber mahallenin hemen karşısında Kavaklı Mescidi Mahallesi yer almaktadır. Zeki Çelikkol da bu ifadeyi doğrularcasına Demirli Camii'nin bulunduğu yeri Kavaklı Mescid'in karşısı olarak belirtmiştir ${ }^{62}$.

Karş11klı olarak yer alan bu mahallelerin güneyinde, Recep Paşa Camii Mahallesi ile Piyaleddin Mescidi Mahallesi yer almaktadır. 1831 yılı nüfus sayımı verilerine göre her iki mahallenin de oldukça düşük bir nüfusa sahip olduğu bilinmektedir. Kentin en güneyinde, kent surlarının hemen bitişiğinde yer alan Alemnak Mescidi Mahallesi de düşük nüfusa sahip mahallelerdendir.

Bu mahallelerin dışında İbrahim Paşa Camii Mahallesi'nden bahsedilebilir. Mahallenin Sokrates Caddesi'nden başlayarak geniş bir alanı kapsadığı düşünülmektedir. Mahalleye ait nüfus sayımı verileri de bu bilgiyle paralellik göstermektedir. Bu mahallenin güneyinde, kent surları ile sınırlanan Hüdai Mescidi Mahallesi yer almaktadır. $\mathrm{Bu}$ mahalle de yine diğer mahallelere oranla daha kalabalık bir mahalledir.

Kentin doğu kesiminde Yeniçeri Mescidi Mahallesi bulunmaktadır. Mahalle kuzeyde deniz surları güneyde, Dolaplı Mescidi Mahallesi ile sınırlandırılmıştır. Dolaplı Mescidi Mahallesi'nin güneyinde Kızıl Kapı sur kapısını da içine alan Çizmeci Mescidi Mahallesi bulunmaktadır. Mescit bu sebeple Kızıl Kapı Mescidi olarak da bilinmektedir.

Şehrin en doğusunda Memi Şeyh Mescidi Mahallesi ve İlk Mihrap Mescidi Mahallesi yer almaktadır. Bu mahallelerin doğusunda hiçbir cami ve mescit yapısına ulaşılamamıştır. Buna karşın bölgede sinagog olarak kullanılan bir yapıya rastlanmış-

62 Çelikkol, Rodos 'taki Türk Eserleri ve Tarihçe, 54. 
tır. Bu sebeple nüfus sayımı verilerinde yer alan iki Yahudi mahallesi olan Havra-i Kebir ve Havra-i Sagir mahallelerinin de burada yer alabileceği düşünülmektedir. Yahudi mahallelerinin bu anlamda kentin en göz alıcı mahalleleri olduğu ve Gümrük Limanı ile kale duvarı arasında kalan bir bölgede yer aldığı söylenmektedir ${ }^{63}$. Ayrıca bu mahallede Şövalyeler döneminde inşa edilmiş bir kilisenin varlığından da söz edilmektedir. Buna ek olarak İstanbul, Selanik gibi diğer Osmanlı liman kentlerinde de gayrimüslimlerin ticari faaliyetlerinden dolayı limana yakın bölgelere yerleştikleri görülmektedir. Tüm bu veriler göz önüne alındığında kentin en doğusunda yer alan bu bölgede iki Yahudi mahallesinin yer alabileceği söylenebilir.

\section{Sonuç}

On İki Adalar içerisinde önemli bir liman kenti konumunda olan Rodos Adası, kale içi bölgesine yönelik yapılmış olan bu çalışma kapsamında Osmanlı döneminde inşa edilmiş yedi adet caminin ve cami ya da mescide dönüştürülen yirmi bir adet yapının yerleri harita üzerinde gösterilmiştir. Yine tüm bu yapı grubunun plan şemaları ve kesitleri de katalog haline getirilerek belgelenmiştir. Belgelenen yirmi sekiz adet yapının, büyük bir bölümünün Rodos mahallelerine ismini verdiği görülmektedir. Çalışma kapsamında bu yapılar ile mahalle eşleşmesi yapılarak mevcut mahallelerin yerleri ve olası sınırları haritalanmıştır.

Bu doğrultuda Rodos kent kurgusunun, Osmanlı Devleti'nin idaresinde bulunan diğer kentlerle benzerlikler taşıdığı söylenebilir. Bu benzerlikler şu şekilde belirtilebilir:

- Osmanlı kentlerinde vezir, subaşı, sancak valisi gibi imparatorluk ve eyalet yönetimlerinin üst kademelerinde bulunan kişilerin gücünü temsil eden saraylar, konaklar, selâtin camileri ve külliyeler kentin odak veya referans noktalarını oluşturmak$\operatorname{tad}^{64}{ }^{64}$. Bu kapsamda Frenk Hisarı olarak isimlendirilen bölgenin Rodos kentinin odak noktası veya referans noktası olduğu söylenebilir. Kanuni Sultan Süleyman’ın adayı ele geçirdikten sonra imar faaliyetlerini başlattığı bu bölge, kentin önemli camilerinden olan Cami-i Kebir, Süleymaniye Camii, imareti ve hamamı başta olmak üzere birçok önemli yapı grubunu içermektedir. Bölge ayrıca başta Kırım Hanları'nın sürgünde yaşadıkları saraylar olmak üzere önemli başka yapıları da içermektedir.

- Dinsel farklılıklara bağlı olarak toplumun kent içerisinde farklı bölümlere ayrılması Osmanlı kentlerinde sıklıkla karşılaşılan bir durumdur ${ }^{65}$. Bu durum Rodos kentinde net bir şekilde kendini göstermektedir. Bu kapsamda Rodos’ta sadece Müslüman

63 Örenç, Yakın Dönemimizde Rodos ve On İki Ada, 186

64 Oya Hayriye Saf ve Emre Ergül, “Osmanlı Toplumu Sosyal Yapısının Kent Düzenindeki Temsili,” SKETCH: Journal of City and Regional Planning 1(1), 16.

65 Saf ve Ergül, "Osmanlı Toplumu Sosyal Yapısının Kent Düzenindeki Temsili,”, 17. 
halkın ikamet ettiği, gayrimüslimlerin ise kale dışında yaşadıkları görülmektedir. Kale içi bölgesinde iki Yahudi mahallesi, Müslüman mahallelerinden ayrışarak kentin diğer ucunda limanla ilişkili olarak kurgulanmıştır. Kale içi bölgesinde yer alan yirmi bir Müslüman mahallesi, bağlı oldukları cami veya mescitten isimlerini almıştır. Bir başka deyişle Müslüman ve Yahudi halk kent içerisinde ayrışarak dinî inanışlarına göre kentin farklı bölgelerinde konumlanmışlardır.

- Kentin hanlar, kervansaraylar, bedestenler ve kapalı çarşı gibi örgütler etrafında lokalize olmas1 yine Osmanlı kentlerinde sik rastlanan bir durumdur ${ }^{66}$. Rodos kentinde de bu bağlamda benzer özellikler görülmektedir. Kentte yer alan mahalleler, Şövalyeler Caddesi'nde yer alan çarşı etrafina konumlanarak gelişmiştir. Bu anlamda Şövalyeler Caddesi'nin iki tarafina yerleşen dükkânlar önemli bir aks oluşturmaktadır. Bu aks en sonunda Süleymaniye Camii gibi kentin önemli bir yapısıyla tamamlanmaktadır.

Özetle, tipik Osmanlı kent kurgusunun net bir şekilde Rodos kentinde de gözlemlendiği, kentte bulunan dinî yapıların bu kurgu üzerinde etkili olduğu söylenebilir. Bunun yanı sıra kent kurgusunun Antik Yunan'ın ızgara planı başta olmak üzere, Bizans ve Şövalyeler dönemine ait önemli izler taşıdığ 1 ve kentin gelişiminde tüm bu verilerin etkili olduğu söylenebilir.

Hakem Değerlendirmesi: Dış bağımsız.

Çıkar Çatışması: Yazar çıkar çatışması bildirmemiştir.

Finansal Destek: Yazar bu çalışma için finansal destek almadığını beyan etmiştir.

Teşekkür: Bu makalenin yazım aşamasındaki paylaşımları ve yardımları için değerli hocam Prof. Dr. Aygül Ağır'a teşekkürlerimi sunarım.

Peer-review: Externally peer-reviewed.

Conflict of Interest: The author has no conflict of interest to declare.

Grant Support: The author declared that this study has received no financial support.

Acknowledgement: I would like to thank my dear teacher Prof. Dr. Aygül Ağır for sharing and helping with the writing of this article

66 Saf ve Ergül, “Osmanlı Toplumu Sosyal Yapısının Kent Düzenindeki Temsili,”, 17. 


\section{Kaynakça/References}

Balducci, Hermes. Rodos 'ta Türk Mimarisi. Çev. Celalettin Rodoslu. Ankara: Türk Tarih Kurumu Yayınlar1, 1987.

Braudel, Fernard. Akdeniz ve Akdeniz Dünyası. 1 cilt. Çev. Mehmet Ali Kılıçbay. İstanbul: Eren Yayınc1lık, 1989.

Braudel, Fernard. Akdeniz ve Akdeniz Dünyası. 2 cilt. Çev. Mehmet Ali Kılıçbay. İstanbul: Eren Yayınc1lik, 1990.

Byzart. "Moschea di Enderum o Kanturi Già Chiesa di S.ta Maria al Castello.” Erişim 09 Ocak 2021, https://cmc.byzart.eu/items/show/88668/.

Çelik, Bülent ve Uğur Ünen. "XVIII. Yüzyılda Rodos'un Sosyo-Ekonomik, Dinî ve Kültürel Durumu.” Adnan Menderes Üniversitesi Sosyal Bilimler Enstitüsü Dergisi 2/2 (2015): 52-73.

Çelikkol, Zeki. Rodos 'taki Türk Eserleri ve Tarihçe. Ankara: Türk Tarih Kurumu Yayınları, 1986.

De Lamartine, Alphonse. Oeuvres Complétes de Lamartine. Vol.1. Paris: Charles Cosselinet Furne Editeurs, 1836.

Ergenç, Özer. "Osmanlı Şehirlerinde Mahallenin İşlev ve Nitelikleri Üzerine”. Osmanlı Araştırmaları 4 (1984): 69-78.

Evliyâ Çelebi. Evliyâ Çelebi Seyahatnâmesi. IX. Kitap. Haz. Yücel Dağl1, Seyit Ali Kahraman ve Robert Dankoff. İstanbul: Yapı Kredi Yayınları, 2005.

Gabriel, Albert. La Cité de Rhodes, MCCCX-MDXXII Topographie Architecture Militaire. Paris: E. de Boccard, 1921.

Gabriel, Albert. La Cité de Rhodes, MCCCX-MDXXII Architecture Civile et Religieuse. Paris:

E. de Boccard, 1923.

İstanbul Üniversitesi Nadir Eserler Kütüphanesi (NEK). Sultan II. Abdulhamid Dönemine Ait Fotoğraf Albümleri.

Kiel, Machiel. "Rodos.” Türkiye Diyanet Vakfi İslâm Ansiklopedisi. C.35. İstanbul: Diyanet Vakfi Yayınlar1, 2008, 155-158.

Kiel, Machiel. "Bir Taraftan İlgisizlik ve Yıkım Diğer Taraftan Özenli Onarım Arasında Rodos ve İstanköy’deki Osmanl1-Türk Mimari Eserleri,” Rodos ve İstanköy Türk Vakıfları. Konya: Eğitim Yayınevi, 2019, 205-213.

Konuk, Neval. Midilli, Rodos. Sakız ve İstanköy'de Osmanlı Mimarisi. Ankara: Stratejik Araştırmalar Merkezi, 2008.

Küçük, Cevdet. "Oniki Ada.” Türkiye Diyanet Vakfi İslâm Ansiklopedisi. C. 33. İstanbul: Diyanet Vakfi Yayınları, 2007, 353-355.

Maglio, Emma. "At the Periphery of the Empire: Urban Restructuring and Architectural Transformation in Ottoman Rhodes." Lonaard Magazine 2 (9) (2012): 59-74.

Matton, Raymond. Villes et Paysages de Gréce. Atina: Institu Francais D’Athenes, 1959.

Örenç, Ali Fuat. Yakın Dönemimizde Rodos ve On İki Ada. İstanbul: Doğu Kütüphanesi, 2006.

Rossi, Ettore. Assedio e Conquista di Rodi nel 1522 Secondo le Relazioni Edite ed Inedite dei Turchi con una Notizia Sulla Biblioteca Hâfiz di Rodi. Roma: Libreria Di Scienze e Lettere, 1927.

Saf, Oya Hayriye ve Emre Ergül. "Osmanlı Toplumu Sosyal Yapısının Kent Düzenindeki Temsili.” SKETCH: Journal of City and Regional Planning 1(1): 15-34. 
